\section{Planting Depth During Container Production and Landscape Establishment Affects Growth of Ulmus parvifolia}

\author{
Donita L. Bryan ${ }^{1}$ \\ University of Wisconsin-Platteville, School of Agriculture, 1 University \\ Plaza, 312 Pioneer Tower, Platteville, WI 53818-3099
}

Michael A. Arnold and Astrid Volder

Department of Horticultural Sciences, Texas A\&M University, College Station, TX 77843-2133

\author{
W. Todd Watson \\ Department of Ecosystem Science and Management, Texas A\&M University, \\ College Station, TX 77843-2138
}

Leonardo Lombardini

Department of Horticultural Sciences, Texas A\&M University, College Station, TX 77843-2133

John J. Sloan

Texas AgriLife Research and Extension Center-Dallas, Dallas, TX 75252

Luis A. Valdez-Aguilar

Centro de Investigación en Química Aplicada, Saltillo, Coah, 25100, México

Andrew D. Cartmill

Department of Horticultural Sciences, Texas A\&M University, College Station, TX 77843-2133

Additional index words. container nursery production, potting-up, up-canning, shifting, landscape installation, tree establishment, relative growth rate, lacebark elm

\begin{abstract}
Planting depth during container production may influence plant growth, establishment, and subsequent landscape value. A lack of knowledge about the effects of common transplanting practices may lead to suboptimal performance of planted landscape trees. Planting depth, i.e., location of the root collar relative to soil grade, is of particular concern for posttransplant tree growth both when transplanted to larger containers during production and after transplanting into the landscape. It is unknown whether negative effects of poor planting practices are compounded during the production phases and affect subsequent landscape establishment. This study investigated effects of planting depth during two successive phases of container production $(10.8 \mathrm{~L}$ and 36.6 L) and eventual landscape establishment using lacebark elm (Ulmus parvifolia Jacq.). Tree growth was greater when planted at grade during the initial container (10.8 L) production phase and was reduced when planted $5 \mathrm{~cm}$ below grade. In the second container production phase $(36.6 \mathrm{~L})$, trees planted above grade had reduced growth compared with trees planted at grade or below grade. For landscape establishment, transplanting at grade to slightly below or above grade produced trees with greater height on average when compared with planting below grade or substantially above grade, whereas there was no effect on trunk diameter. Correlations between initial growth and final growth in the field suggested that substantial deviations of the original root to shoot transition from at-grade planting was more of a factor in initial establishment of lacebark elm than the up-canning practices associated with planting depth during container production.
\end{abstract}

Landscape trees are increasingly being produced using container nursery systems in comparison with traditional field production practices (U.S. Department of Agriculture, 2007). In contrast to traditional field production, container production requires a series of transplanting events in which trees are

sequentially transferred to larger containers (potting-up/up-canning). This may cause problems because trees can potentially be planted too deep or too shallow at each upcanning. Variability in planting depth, defined as the location of the root collar relative to soil surface (grade), is of particular con- cern because optimum planting depth may vary among species and may be dependent on cultural practices and/or environmental conditions (Arnold et al., 2005, 2007; Ball, 1999; Browne and Tilt, 1992; Day et al., 2009; Drilias et al., 1982; Gilman and Grabosky, 2004; Wells et al., 2006). Little is known about the effects of relatively small, yet cumulatively significant changes in transplanting depth during container production and there may be an opportunity to improve plant performance during container production and when transplanted in the landscape by improving transplanting practices. We suggest that changes in transplanting depth during container production may be a result of numerous interrelated nursery practices, including 1) inappropriate size of plant material to container size ratio at up-canning; 2) shrinkage and loss of substrate; 3 ) excessive filling of the container and compaction of substrate; 4) hiding graft unions or pruning scars; and 5) general carelessness or lack or training.

If trees are planted too deep during the production phase, the detrimental effects of below-grade planting may be compounded during landscape installation (Fare, 2005). The few studies conducted on the effect of planting depth during container production show contrasting results depending on container size, planting depths, and species used during container production (Fare, 2005; Giblin et al., 2005; Gilman and Harchick, 2008). Our goal in this study was to determine if transplanting practices during container production through two up-canning events would affect subsequent landscape performance. Therefore, a series of experiments was conducted on Ulmus parvifolia Jacq (lacebark elm), a common landscape tree in urban environments, to determine the effects of different transplanting depths during container production and the subsequent effects on landscape establishment. Specifically, we tested whether 1) trees that were initially planted with root collars below grade or above grade in container production and then brought back to grade during successive up-canning or when placed in the landscape performed as well as trees that were consistently planted with root collars at grade; and 2) below-grade planting in containers would exacerbate any adverse effects of below-grade planting in the landscape.

\section{Materials and Methods}

Expt. 1: Effect of planting depth during container $(10.8 \mathrm{~L})$ production

Cultural conditions. Ulmus parvifolia seeds were collected in College Station, TX (lat. $30^{\circ} 37.78^{\prime} \mathrm{N}$, long. $96^{\circ} 20.51^{\prime} \mathrm{W}$ ) in late Nov. 2004 and stored in the dark in a cold room (Bally Case and Cooler, Inc, Bally, PA) at $2{ }^{\circ} \mathrm{C}$ until required. Seeds were soaked for $48 \mathrm{~h}$ in aerated (RENA ${ }^{\circledR}$ Air 100 Pump; Aquarium Pharmaceuticals, Inc., Chalfont, PA) citric acid (EM Science; EM Industries, Inc., Gibbstown, NJ) solution $\left(100 \mathrm{mg} \cdot \mathrm{L}^{-1}\right)$ in May 2005. Seeds were rinsed in reverse osmosis (RO)-treated water and planted in $10 \mathrm{~cm} \times 36 \mathrm{~cm} \times 51 \mathrm{~cm}$ 
black plastic flats (Dyna-flat ${ }^{\mathrm{TM}}$ Kadon, Corp., Dayton, $\mathrm{OH}$ ) containing a commercial substrate (Metro-Mix ${ }^{\circledR} 700$ Series; Sun Gro ${ }^{\circledR}$, Bellevue, WA) and then placed in a greenhouse at Texas A\&M University, College Station, TX. Emerging seedlings were fogged [Fogg-It Nozzle (3.785 L·min ${ }^{-1}$ ); Fogg-It Nozzle Co., San Francisco, CA] manually as required with $\mathrm{RO}$ water.

Uniform seedlings $(\approx 1.5 \mathrm{~cm}$ in height $)$ were transplanted, after $\approx 16 \mathrm{~d}$, into 0.295 -L green plastic containers (Dillen Products, Middlefield, $\mathrm{OH}$ ) with the point where the roots emerged from the stem placed just under the substrate (Metro-Mix ${ }^{\circledR} 700$ Series; Sun Gro ${ }^{\circledR}$ ) surface (grade). Transplanted seedlings were maintained under shade (55\% light exclusion) in a graveled nursery at Texas A\&M University Horticultural Gardens. Seedlings were fertigated $\left(0.27 \mathrm{~L} \cdot \mathrm{min}^{-1}\right.$ flow rate) with sulfuric acid-injected water ( $\mathrm{pH} 6.3$ to 6.5) containing $50 \mathrm{mg} \cdot \mathrm{L}^{-1}$ of nitrogen from a water-soluble fertilizer (Peter Professional ${ }^{\circledR}$ Acid Special water soluble fertilizer, $21 \mathrm{~N}-3.1 \mathrm{P}-5.8 \mathrm{~K}$; Scott's Company, Marysville, $\mathrm{OH}$ ).

Young trees (liners), $\approx 10 \mathrm{~cm}$ in height, were transplanted after $50 \mathrm{~d}$ into 2.6 -L black plastic containers (C-300S Classic; Nursery Supplies, Inc., Chambersburg, PA) with their root collars maintained at substrate grade. Root balls were held intact by well-formed roots. The container substrate (composted pine bark mulch; Earth's Finest Black Diamond Mulch; The LetCo Group, Dallas, TX) had the following characteristics: $59.2 \%$ or-

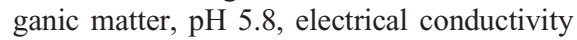
(EC) $0.862 \mathrm{dS} \cdot \mathrm{m}^{-1}$, and nutrient concentrations $\left(\mu \mathrm{g} \cdot \mathrm{g}^{-1}\right)$ of 7.4 nitrogen, 0.8 phosphorus, 1.7 potassium, 12.1 calcium, 1.4 magnesium, 0.1 zinc, 4.0 iron, 0.3 manganese, 0.01 copper, and 2.8 sodium (Soil, Water, and Forage Testing Laboratory, Texas A\&M University, College Station, TX). The substrate was amended with the following, $7 \mathrm{~kg} \cdot \mathrm{m}^{-3} 15 \mathrm{~N}-$ 3.9P-9.9K controlled-release fertilizer (Scotts Osmocote ${ }^{\circledR}$ Plus 15-9-12; Scotts-Sierra Horticultural Products Co., Marysville, $\mathrm{OH}), 4$ $\mathrm{kg} \cdot \mathrm{m}^{-3}$ dolomitic limestone (Austin White Lime Company, Austin, TX), $2 \mathrm{~kg} \cdot \mathrm{m}^{-3}$ gypsum (Hoedown ${ }^{\text {TM }}$ Standard Gypsum LP, Fredericksburg, TX), and $1 \mathrm{~kg} \cdot \mathrm{m}^{-3}$ micronutrients (Scotts Micromax ${ }^{\circledR}$ micronutrients; ScottsSierra Horticultural Products Co.). Bulk density of the amended substrate was $0.25 \pm 0.01$ $\mathrm{g} \cdot \mathrm{cm}^{-3}$. Liners were maintained in the nursery

\footnotetext{
Received for publication 3 Aug. 2009. Accepted for publication 30 Oct. 2009.

This project was funded in part by Texas AgriLife Research (formerly the Texas Agricultural Experiment Station), grants from the Tree Research and Education Endowment Fund, and the J. Frank Schmidt Family Charitable Trust.

Mention of a trademark, proprietary product, or vendor does not constitute a guarantee or warranty of the product by the authors, Texas A\&M University, or Texas AgriLife Research and does not imply its approval to the exclusion of other products or vendors that also may be suitable.

${ }^{1}$ To whom reprint requests should be addressed; e-mail bryand@uwplatt.edu.
}

under 55\% light exclusion and fertigated as previously described.

Trees were transplanted from 2.6-L containers after $\approx 100 \mathrm{~d}$ (Oct. 2005) into $10.8-\mathrm{L}$ black plastic containers (1200C Classic; Nursery Supplies, Inc.) with their root collars at substrate grade, $5 \mathrm{~cm}$ below grade, or $5 \mathrm{~cm}$ above grade (Fig. 1A). Root balls were held intact by well-formed roots. Trees were maintained in the nursery under 55\% light exclusion and fertigated as previously described. Mean $( \pm \mathrm{SE})$ daily maximum/minimum temperature and precipitation were $23.0 \pm 0.45$ / $10.4 \pm 0.47^{\circ} \mathrm{C}$ and $2.1 \pm 0.6 \mathrm{~mm}$, respectively (Office of the Texas State Climatologist, Department of Atmospheric Sciences, Texas A\&M University, College Station, TX). Trees were staked (1.2-m bamboo stakes) and tied to maintain a central leader.

Plant growth parameters. Growth measurements were recorded on randomly selected trees at harvest $(\mathrm{n}=7) \approx 200 \mathrm{~d}$ (May 2006) after transplanting into 10.8 -L black plastic containers and included tree height (from existing substrate surface grade to apical tip), trunk diameter $(\approx 15 \mathrm{~cm}$ above existing soil line), and leaf, stem (from just above root collar to apex), root, and total plant dry mass (DM). Roots were separated from the substrate by placing the roots on a series of fine mesh screens $(\approx 1 \mathrm{~cm}, 0.5 \mathrm{~cm}, 1 \mathrm{~mm}$, and $0.5 \mathrm{~mm}$ ) and using running water and forceps to gently remove the substrate from the roots. The series of screens were checked for roots once finished. All tissue samples were placed in paper bags for drying. Tissue samples were dried for $7 \mathrm{~d}$ at $70{ }^{\circ} \mathrm{C}$ and leaf, stem, root, and total DM were recorded.

Statistical design. The experiment was a completely randomized design with three planting depths. There was one tree per container with each container as a single replicate $(n=7)$. Data were analyzed using analysis of variance (ANOVA) in the JMP system for Windows (Release 7.0.2; SAS Institute Inc., Cary, NC).

\section{Expt. 2: Effect of planting depth during container $(36.6 \mathrm{~L})$ production}

Cultural conditions. Randomly selected trees from each planting depth in Expt. 1 $(10.8 \mathrm{~L})$ were transplanted, after $\approx 200 \mathrm{~d}$ (May 2006), into 36.6-L black plastic containers (4000C Classic; Nursery Supplies, Inc.) at the following depths: with existing substrate line maintained at grade, $5 \mathrm{~cm}$ below grade, or $5 \mathrm{~cm}$ above grade (Fig. 1B). Relation of original root collar (in 2.6-L containers) to substrate surface ranged from $10 \mathrm{~cm}$ below grade $(\mathrm{BB})$ (first $\mathrm{B}=$ trees initially planted with root collars $5 \mathrm{~cm}$ below substrate grade in 10.8-L containers and second $\mathrm{B}=$ trees subsequently planted with root collars $5 \mathrm{~cm}$ below substrate surface grade in 36.6-L containers) to $10 \mathrm{~cm}$ above grade (AA) (Fig. 1B). The container substrate (composted pine bark mulch; Earth's Finest Black Diamond Mulch; The LetCo Group) was amended as described previously. Trees were restaked $(1.2-\mathrm{m}$ bamboo stakes) and tied to maintain a central leader. Trees were maintained in the nursery under 55\% light exclusion and fertigated as previously described. Mean $( \pm \mathrm{SE})$ daily maximum/minimum temperature and precipitation were $32.9 \pm 0.3 / 21.7 \pm 0.3{ }^{\circ} \mathrm{C}$ and $3.5 \pm 1.0$ $\mathrm{mm}$, respectively (Office of the Texas State Climatologist) during this growth period.

Plant growth parameters. Height, diameter, and shoot, root, and total plant DM measurements were recorded, as described in

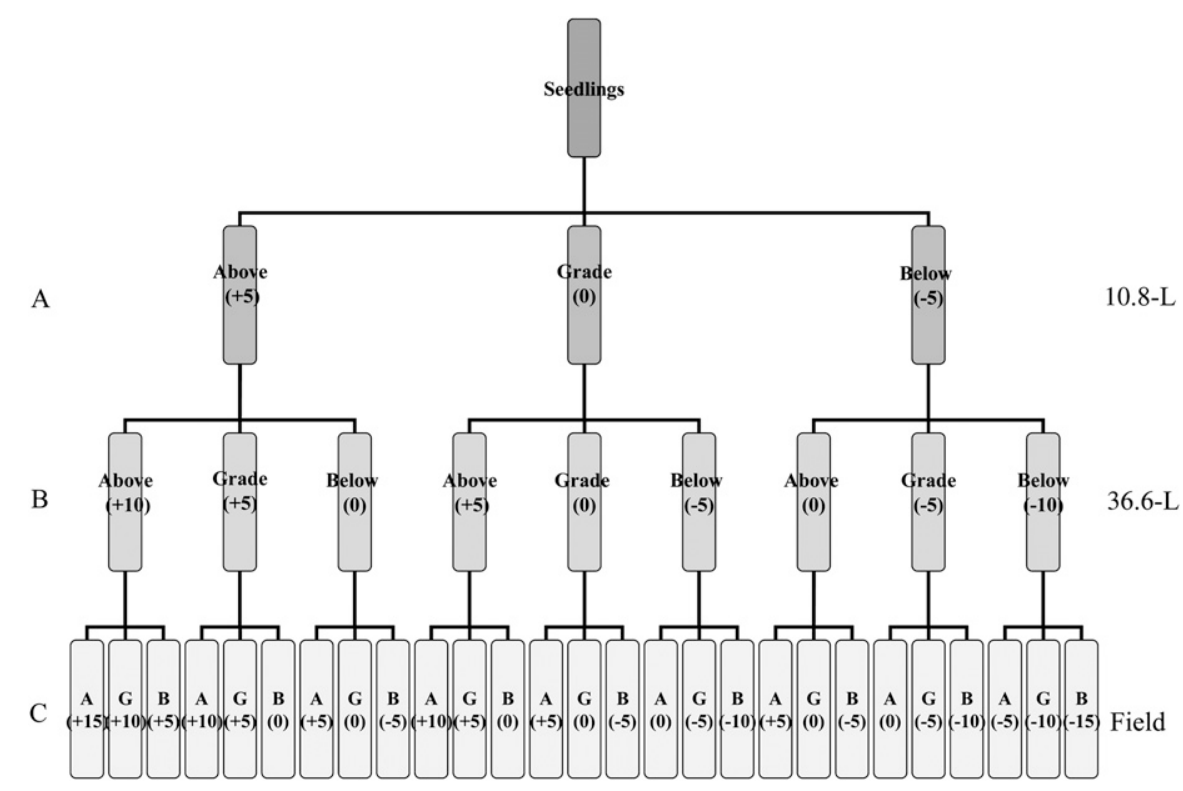

Fig. 1. Experimental design testing for the effect of planting depth during container production on landscape establishment of lacebark elm (Ulmus parvifolia Jacq.). In (A) Expt. 1, trees were transplanted into 10.8L containers; (B) in Expt. 2, trees were transplanted into 36.6-L containers; and (C) in Expt. 3, trees were transplanted into field conditions. Trees were transplanted at one of three planting depths in relation to soil surface (grade). Trees were planted with the top of the existing root ball $5 \mathrm{~cm}$ above grade [Above (A)], at grade [Grade (G)], or $5 \mathrm{~cm}$ below grade [Below (B)]. Numbers in parentheses under the planting depths indicate the original root collar depth in centimeters relative to existing substrate/soil surface. 
Expt. 1, at harvest $\approx 100 \mathrm{~d}$ after transplanting into 36.6-L black plastic containers.

Statistical design. The experiment was a completely randomized design with nine planting depth treatments (Fig. 1B). There was one tree per container with each container as a single replicate $(n=6)$. Data were analyzed using ANOVA in the JMP system for Windows (Release 7.0.2; SAS Institute Inc.).

\section{Expt. 3: Effect of planting depth during} container production on landscape establishment

Cultural conditions. After $\approx 100 \mathrm{~d}$ in 36.6L containers, randomly selected trees from each planting depth in Expt. 2 were transplanted into field conditions (Boonville Series, fine, smectitic, thermic Chromic Vertic Albaqualfs; U.S. Department of Agriculture, Natural Resources Conservation Service, Texas Agricultural Experiment Station, Texas State Soil and Water Conservation Board, 1991) at the Texas A\&M University Horticulture Farm, College Station, TX. Root balls were held intact by well-formed roots. The field soil had a textural analysis of $77 \%$ sand, $11 \%$ silt, and $12 \%$ clay (sandy loam) contained $1.9 \%$ organic matter, $\mathrm{pH} 5.2$, EC $0.09 \mathrm{dS} \cdot \mathrm{m}^{-1}$, and nutrient concentrations $\left(\mathrm{mg} \cdot \mathrm{kg}^{-1}\right)$ of 8 nitrogen, 33 phosphorus, 64 potassium, 283 calcium, 36 magnesium, 0.56 zinc, 133.3 iron, 6.9 manganese, 0.29 copper, 191 sodium, 16 sulfur, and 0.08 boron. Trees were transplanted with existing substrate surface at grade, $5 \mathrm{~cm}$ below grade, or $5 \mathrm{~cm}$ above grade (Fig. 1C). Thus, final relation of root collar in the liner stage to soil line in the landscape ranged from $15 \mathrm{~cm}$ below grade (BBB) to $15 \mathrm{~cm}$ above grade (AAA) (Fig. 1C). Weeds were removed manually on a regular basis to maintain site. Trees were drip-irrigated (T-Tape ${ }^{\circledR}$ T-Systems Intl. Inc., San Diego, CA) as required. Mean $( \pm$ SE) daily maximum/minimum temperature and precipitation were $25.6 \pm 0.41 / 15.0 \pm$ $0.43{ }^{\circ} \mathrm{C}$ and $3.5 \pm 0.6 \mathrm{~mm}$, respectively (Office of the Texas State Climatologist).

Plant growth parameters. Height and trunk diameter were determined at initial transplant and at harvest (365 d), as described previously, and relative growth rate (RGR) was calculated: $R G R=\left(\overline{\ln W_{2}}-\overline{\ln W_{1}}\right)$ $\left(t_{2}-t_{1}\right)$ (Hoffman and Poorter, 2002), where $W_{1}=$ initial height or initial diameter, $W_{2}=$ final height or final diameter, $t_{1}=$ first day of measurement, and $t_{2}=$ final day of measurement.

Statistical design. The experiment was a randomized complete block design with 27 planting depth treatments (Fig. 1C) $(\mathrm{n}=6)$. Data were analyzed using restricted maximum likelihood ANOVA in the JMP system for Windows (Release 7.0.2; SAS Institute Inc.).

\section{Results}

\section{Expt. 1: Effect of planting depth during} container $(10.8 \mathrm{~L})$ production

Planting depth significantly affected tree height, leaf DM, stem DM, and total DM (Table 1). Planting the root collar $5 \mathrm{~cm}$ below grade significantly reduced tree height when compared with planting the root collar at soil grade or $5 \mathrm{~cm}$ above soil grade $(26 \%$ or $16 \%$, respectively) (Fig. 2A). Planting the root collar $5 \mathrm{~cm}$ below grade significantly reduced leaf DM (37\%), stem DM (42\%), and total DM (31\%) when compared with planting the root collar at soil grade (Fig. 2B-D). Planting depth did not affect trunk diameter $(P=0.073)$ or root DM $(P=0.343)$ (data not shown). There was $0 \%$ mortality across treatments.

\section{Expt. 2: Effect of planting depth during} container $(36.6 \mathrm{~L})$ production

Planting depth significantly affected tree height (Table 1) when all nine treatment combinations were compared. Trees planted BG ( $B=$ trees initially planted $5 \mathrm{~cm}$ below sub- strate grade in 10.8 - $\mathrm{L}$ containers and $\mathrm{G}=$ trees subsequently planted at substrate surface grade in 36.6-L containers) were significantly shorter $(29 \mathrm{~cm})$ than trees planted $A B$ $(\mathrm{A}=$ trees initially planted $5 \mathrm{~cm}$ above substrate grade in 10.8-L containers; $\mathrm{B}=$ trees subsequently planted $5 \mathrm{~cm}$ below substrate surface grade in 36.6-L containers), AA, GG, or BB (Fig. 3A). Planting depth significantly $(P=0.004)$ affected trunk diameter (Table 1$)$. Trees planted AA, GB, and BG had significantly smaller trunk diameters than those planted $\mathrm{AB}$ or BB (Fig. 3B). There was $0 \%$ mortality across treatments.

Planting depth significantly affected shoot DM, root DM, and total DM (Table 1). Trees

Table 1. Significance of planting depth ${ }^{\mathrm{z}}$ on growth of lacebark elm (Ulmus parvifolia Jacq.) after $200 \mathrm{~d}$ in 10.8-L containers (Expt. 1) and after $100 \mathrm{~d}$ in 36.6-L containers (Expt. 2).

\begin{tabular}{lcccccccc}
\hline Expt. & $\mathrm{Ht}^{\mathrm{y}}$ & $\begin{array}{c}\text { Trunk } \\
\text { diam }\end{array}$ & $\begin{array}{c}\text { Leaf } \\
\mathrm{DM}\end{array}$ & $\begin{array}{c}\text { Stem } \\
\mathrm{DM}\end{array}$ & $\begin{array}{c}\text { Shoot } \\
\mathrm{DM}\end{array}$ & $\begin{array}{c}\text { Root } \\
\mathrm{DM}\end{array}$ & $\begin{array}{c}\text { Total } \\
\text { DM }\end{array}$ & $\begin{array}{c}\text { Root mass } \\
\text { fraction }^{\mathrm{w}}\end{array}$ \\
\hline 1 & $\leq 0.001^{\mathrm{v}}$ & 0.073 & 0.025 & 0.039 & $\mathrm{~N} / \mathrm{A}^{\mathrm{u}}$ & 0.343 & 0.049 & 0.120 \\
2 & 0.048 & 0.004 & N/A & N/A & 0.001 & 0.020 & $\leq 0.001$ & 0.966 \\
\hline
\end{tabular}

${ }^{\mathrm{z}}$ Root balls planted $5 \mathrm{~cm}$ above substrate grade, at grade, or $5 \mathrm{~cm}$ below grade.

${ }^{y}$ Height measured from soil line to apex of the tree.

${ }^{x}$ Trunk diameter measured $15 \mathrm{~cm}$ above soil line.

${ }^{\text {w}}$ Root dry mass/total dry mass.

vignificance according to analysis of variance. $P$ values presented, $\mathrm{n}=7$.

"Not applicable.
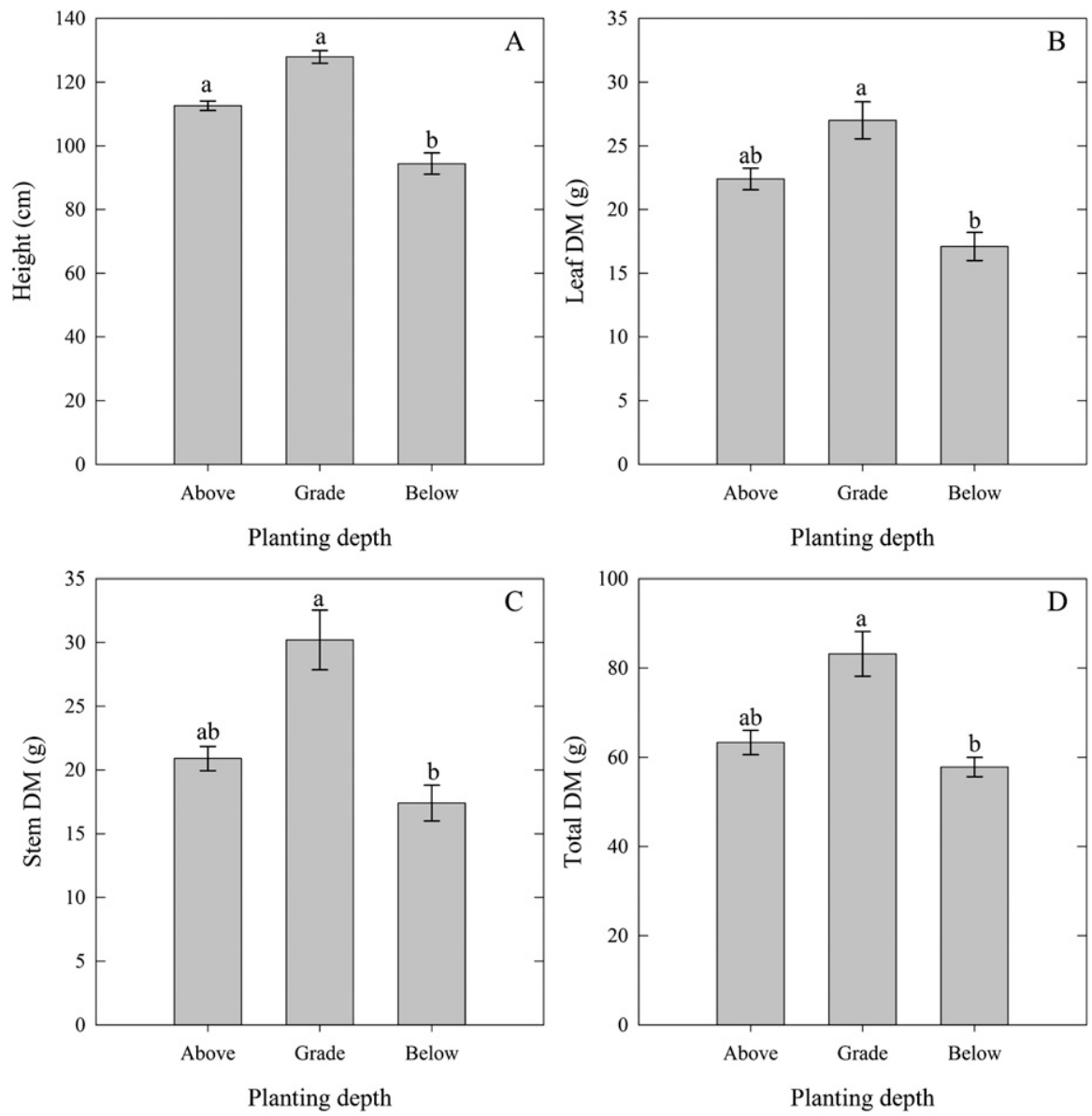

Fig. 2. Effect of planting depth on (A) height (B) leaf dry mass (DM), (C) stem DM, and (D) total DM (leaf, stem, and root DM) of lacebark elm (Ulmus parvifolia) after $200 \mathrm{~d}$ in 10.8-L containers. Root balls were planted $5 \mathrm{~cm}$ above soil grade (above), at soil grade (grade), or $5 \mathrm{~cm}$ below grade (below). Height was measured from soil line to apex of tree. Means $\pm \mathrm{SE}(\mathrm{n}=7)$. Levels with the same letter are not significantly different according to least squares means Tukey honestly significant difference, $\alpha=0.05$. 
planted $\mathrm{GB}, \mathrm{BG}$, and $\mathrm{AA}$ had significantly reduced ( $32 \%$ on average) shoot $\mathrm{DM}$ when compared with trees planted $\mathrm{AB}$ or $\mathrm{BB}$ (Fig. 3C). Trees planted AA had significantly reduced (39\%) root DM when compared with trees planted $\mathrm{AB}$ (i.e., returned to at-grade location at transplant) (Fig. 3D). Trees planted $\mathrm{AB}$ had significantly greater $(28 \%, 31 \%, 35 \%$, or $37 \%$, respectively) total DM when compared with trees planted GG, GB, BG, or AA (Fig. 3E).

\section{Expt. 3: Effect of planting depth during container production on landscape establishment}

Final height was significantly affected by field planting depth (Table 2). Trees planted in the field above grade and at grade were on average $10 \mathrm{~cm}$ taller than trees that were planted below grade (Fig. 4). Planting trees GAG (first $\mathrm{G}=$ trees initially planted at substrate grade in 10.8-L containers, A = trees subsequently planted $5 \mathrm{~cm}$ above grade in 36.6- $\mathrm{L}$ containers, and $\mathrm{G}=$ trees subsequently planted at soil surface grade in the field) resulted in the tallest trees, whereas trees planted GAA resulted in the shortest trees (Fig. 4). The four treatments (GAG, BBA, ABA, GBA) that resulted in the tallest trees had their final root collars (considering the planting depth from the 10.8 -L phase up to the landscape phase) $5 \mathrm{~cm}$ above grade, 5 $\mathrm{cm}$ below grade, or at grade in relation to the soil surface. The five treatments (GAA, ABB, $\mathrm{BAB}, \mathrm{BGB}, \mathrm{BBB})$ that resulted in the shortest trees had their final root collars 5,10 , or $15 \mathrm{~cm}$ below grade with the exception of GAA at $10 \mathrm{~cm}$ above grade. The correlation between initial height and final height was unaffected by container transplanting practices or field transplanting (Fig. 4).

Final trunk diameter was not significantly affected by planting depth (Table 2). The relationship between initial trunk diameter and final trunk diameter (Fig. 5) was unaffected by container transplanting practices or field transplanting. Planting depth did not significantly affect RGR in height or diameter of lacebark elm after 1 year of growth (Table 2). There was $0 \%$ mortality across treatments.

\section{Discussion}

Planting the root collar $5 \mathrm{~cm}$ below grade in 10.8-L containers (Expt. 1) significantly reduced lacebark elm growth when compared with the other planting depths, which may have been the result of the perched water tables that can occur near the bottom of some smaller containers (Bunt, 1988) such as the containers used in this study. Although belowgrade planting was detrimental to tree growth in smaller 10.8-L containers, it appeared beneficial in some cases in larger 36.6-L containers (Expt. 2). Trees planted $\mathrm{AB}(\mathrm{A}=$ trees initially planted $5 \mathrm{~cm}$ above substrate grade in $10.8-\mathrm{L}$ containers and $\mathrm{B}=$ trees subsequently planted $5 \mathrm{~cm}$ below substrate surface grade in 36.6-L containers) and $\mathrm{BB}$ in the $36.6-\mathrm{L}$ containers had the greatest mass at harvest when compared with other
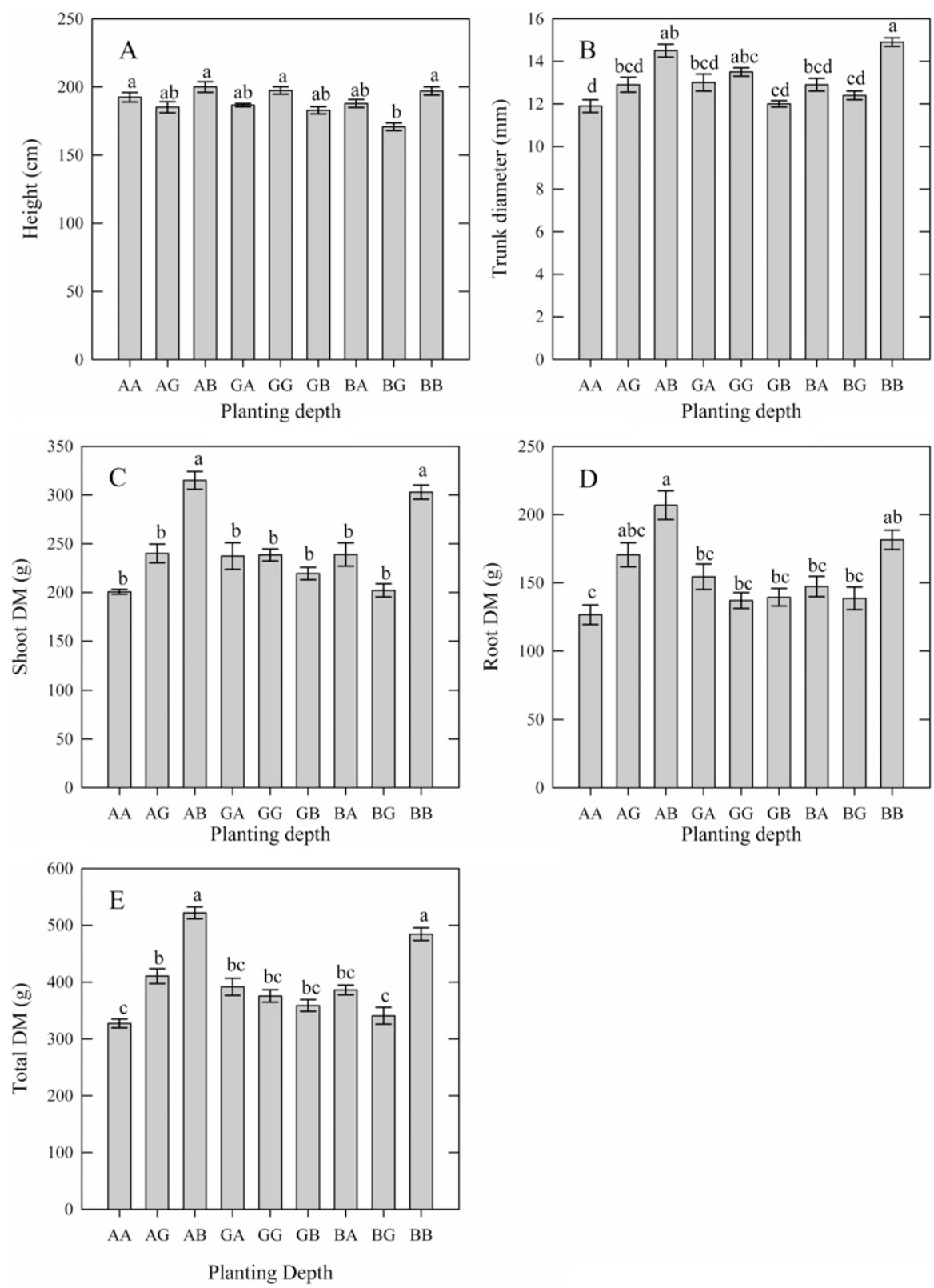

Fig. 3. Effect of planting depth on (A) height, (B) diameter, (C) shoot dry mass (DM), (D) root DM, and (E) total DM of lacebark elm (Ulmus parvifolia Jacq.) after $100 \mathrm{~d}$ in 36.6-L containers. Root balls were planted $5 \mathrm{~cm}$ above soil grade (A), at soil grade $(\mathrm{G})$, or $5 \mathrm{~cm}$ below grade (B). First letter $=10.8-\mathrm{L}$ container planting depth, second letter $=36.6$-L container planting depth. Means $\pm \operatorname{SE}(n=6)$. Levels with same letter are not significantly different according to least squares means Student's $t$ test, $\alpha=$ 0.05 .

Table 2. Significance of planting depth on growth of lacebark elm (Ulmus parvifolia Jacq.) after 1 year in the field.

\begin{tabular}{|c|c|c|c|c|}
\hline Fixed effect test & $\mathrm{Ht}^{\mathrm{z}}$ & Trunk diam $^{y}$ & $\mathrm{RGR}_{\mathrm{ht}}{ }^{\mathrm{x}}$ & $\mathrm{RGR}_{\text {diam }}$ \\
\hline Container depth ${ }^{\mathrm{w}}$ & $0.604^{\mathrm{v}}$ & 0.076 & 0.132 & 0.233 \\
\hline Field depth ${ }^{u}$ & 0.028 & 0.182 & 0.612 & 0.494 \\
\hline Container depth $\times$ field depth & 0.032 & 0.130 & 0.825 & 0.917 \\
\hline
\end{tabular}

${ }^{2}$ Height measured from soil line to apex of tree.

${ }^{y}$ Trunk diameter measured $15 \mathrm{~cm}$ above soil line.

${ }^{x}$ Relative growth rate (RGR) calculated according to Hoffman and Poorter (2002). $R G R=\left(\overline{\ln W_{2}}-\overline{\ln W_{1}}\right) /\left(t_{2}-t_{1}\right)$

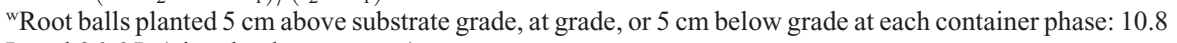
$\mathrm{L}$ and 36.6 L (nine depth treatments).

vSignificance according to restricted maximum likelihood. $P$ values presented, $\mathrm{n}=6$.

"Root balls planted $5 \mathrm{~cm}$ above soil grade, at grade, or $5 \mathrm{~cm}$ below grade into field conditions after container production phases. 

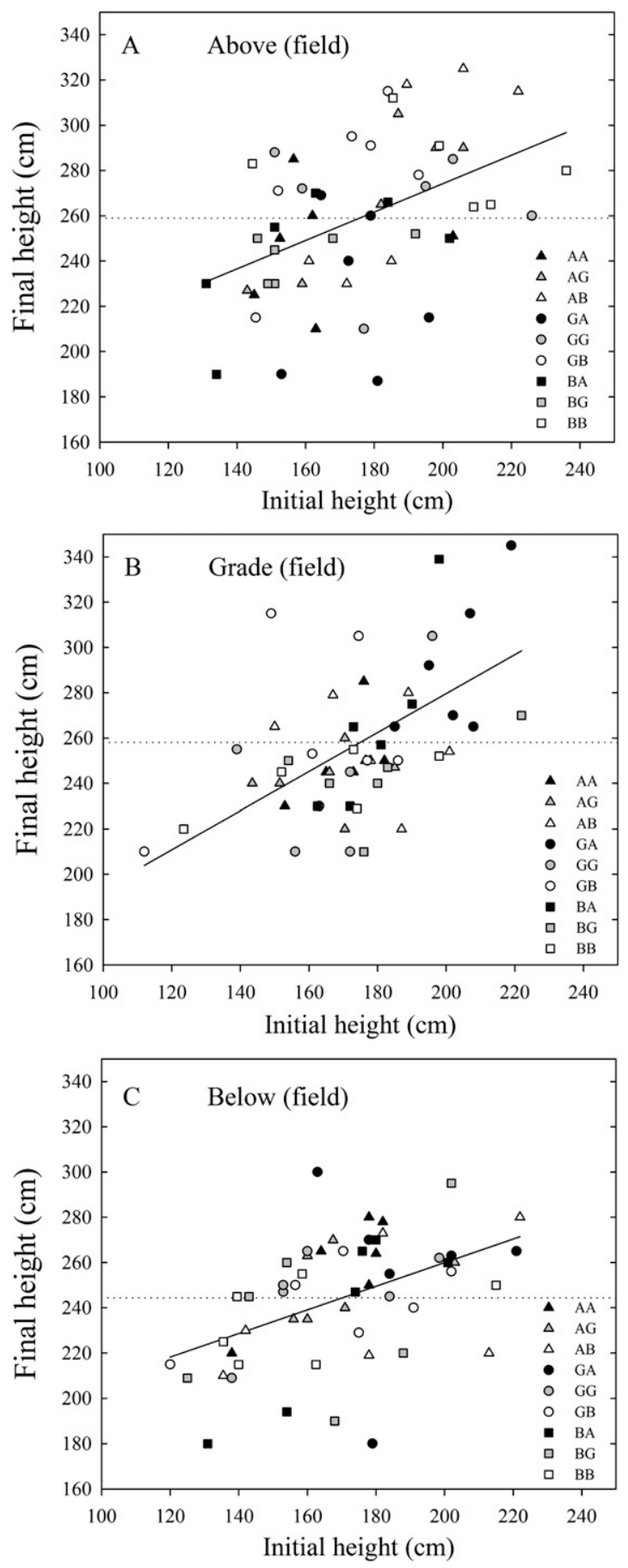

Fig. 4. Correlation of initial tree height and final tree height (1 year of growth in field) of lacebark elm (Ulmus parvifolia Jacq.). Root balls were transplanted $5 \mathrm{~cm}$ above soil grade (A), at soil grade (G), or 5 $\mathrm{cm}$ below grade $(\mathrm{B})$. First letter $=10.8$ - $\mathrm{L}$ container planting depth and second letter $=36.6$ - $\mathrm{L}$ container planting depth. Root ball depth at field planting was (A) $5 \mathrm{~cm}$ above grade, (B) at grade, or (C) $5 \mathrm{~cm}$ below grade. Height was measured from soil line to apex. Means $\pm \mathrm{SE}(\mathrm{n}=6)$. Solid line represents the linear regression: $(\mathbf{A}) \mathrm{y}=148.7(29.3)+0.627(0.165) \mathrm{x}, r^{2}=0.217 ;(\mathbf{B}) \mathrm{y}=107.6(33.2)+0.860(0.19) \mathrm{x}$, $r^{2}=0.287$; and $(\mathbf{C}) \mathrm{y}=155.7(23.2)+0.521(0.135) \mathrm{x}, r^{2}=0.222$. Dotted line represents mean of final tree height across treatments.

treatments. In both treatments, there was at least a 5-cm layer of substrate between the upper surface and the 10.8-L root ball once transplanted to the $36.6-\mathrm{L}$ container. This may have allowed for adequate oxygen flow to the original root ball as well as moisture retention resulting from the buffer of media from the exposed surface. Similarly, bare root red maples (Acer rubrum L. 'Autumn
Flame' and 'Brandywine'), serviceberry [Amelanchier arborea (F. Michx.) Fernald $x$ A. grandiflora (Mich. F.) Fern.], and zelkova [Zelkova serrata (Thunb.) Mak. 'Green Vase'] were unaffected (height and caliper) when planted 10.2 or $15.2 \mathrm{~cm}$ deep in containers (container size not reported) using a pine bark substrate (Fare, 2005). Fare (2005) suggested that pine bark substrate enhanced oxygen flow to the roots, whereas planting deep in landscape settings where field soil may be denser might cause a problem as a result of decreased oxygen movement. However, in the same study, Fare (2005) reported that when bare root dogwood (Cornus florida L. 'Cherokee Princess') trees were planted 10.2 or $15.2 \mathrm{~cm}$ deep, shoot and root growth were reduced compared with trees planted shallower at depths of 0 and $5.1 \mathrm{~cm}$, thus indicating that some species are more susceptible to deep planting than others, even when a low-density substrate is used to cover the root ball.

Lacebark elm trees planted BB had the greatest trunk diameters, whereas trees planted AA had the smallest. Trees planted BB and AA were at opposite ends of the spectrum in regard to where the original root collar was located in relation to the substrate surface. Trees planted BB had the original root collar located $10 \mathrm{~cm}$ below the substrate surface, whereas trees planted AA had the original root collar located $10 \mathrm{~cm}$ above the substrate surface. In the 36.6-L containers, roots of trees planted $\mathrm{BB}$ would not have been as affected by a perched water table (like in the 10.8-L containers), and with the deeper planting, trees planted $\mathrm{BB}$ would have been buffered from the typical drying that occurs in upper levels of container substrates (Bunt, 1988). In contrast to our findings of greater diameters of trees planted deep in containers, Giblin et al. (2005) reported that when bare root green ash (Fraxinus pennsylvanica Marsh.), crabapple (Malus Tourn. ex L. $\times$ 'Spring Snow'), and swamp white oak (Quercus bicolor Willd.) trees were planted into \#10 containers (substrate not given, volume not given, range of 34 to $43 \mathrm{~L}$ in industry) in a pot-in-pot system at depths of $0,5,10$, and $15 \mathrm{~cm}$, green ash and swamp white oak had greater caliper growth at $0-\mathrm{cm}$ depth when compared with the $15-\mathrm{cm}$ depth, whereas the crabapples were not significantly different (Giblin et al., 2005). The discrepancy between their and our findings may be related to differences in substrate used, size of the trees, or could be species-specific. Giblin et al. (2005) also reported that the root volume of all three species decreased with increased planting depth after 4 months. This is also opposite to our finding that root mass was greater in two of the three deep planting treatments of Expt. 2 (AB and $\mathrm{BB}$ ) compared with the root mass of trees planted consistently above grade (AA). Gilman and Harchick (2008) reported that live oak (Quercus virginiana Mill. 'SDLN' Cathedral Oak $\left.{ }^{\circledR}\right)$ trees planted $6.35 \mathrm{~cm}$ deep into $10.1-\mathrm{L}$ air root pruning containers, followed by planting $6.35 \mathrm{~cm}$ deep (total $12.7 \mathrm{~cm}$ from surface) into 45.4-L containers, and then $6.35 \mathrm{~cm}$ deep (total $19 \mathrm{~cm}$ from surface) into 158.8-L containers had the most severe root defects (fewer and smaller diameter roots) than those planted $1.3,3.8,6.4,8.9$, or $11.4 \mathrm{~cm}$ deep in 10.1-L containers and maintained at the same depth for subsequent transplants. After 40 months, live oaks planted initially at 3.8and $8.9-\mathrm{cm}$ depths had significantly greater 

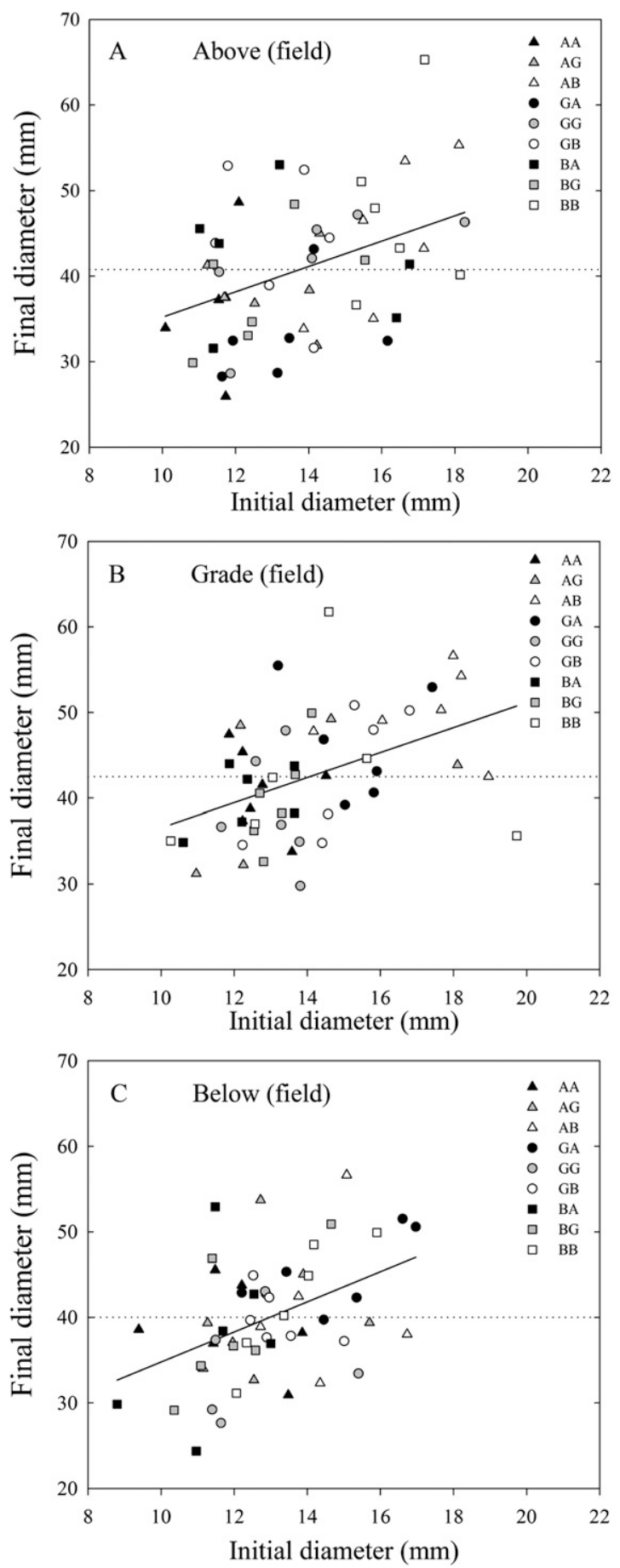

Fig. 5. Correlation of initial trunk diameter and final trunk diameter (1 year of growth in field) of lacebark elm (Ulmus parvifolia Jacq.). Root balls were transplanted $5 \mathrm{~cm}$ above soil grade (A), at soil grade (G), or $5 \mathrm{~cm}$ below grade $(\mathrm{B})$. First letter $=10.8$-L container planting depth and second letter $=36.6-\mathrm{L}$ container planting depth. Root ball depth at field planting was (A) $5 \mathrm{~cm}$ above grade, (B) at grade, or (C) $5 \mathrm{~cm}$ below grade. Trunk diameter was measured $\approx 15 \mathrm{~cm}$ above existing soil surface. Means $\pm \mathrm{SE}$ $(\mathrm{n}=6)$. Solid line represents the linear regression: $(\mathbf{A}) \mathrm{y}=20.37(6.577)+1.482(0.472) \mathrm{x}, r^{2}=0.159 ;(\mathbf{B})$ $\mathrm{y}=21.96(5.803)+1.459(0.408) \mathrm{x}, r^{2}=0.198$; and $(\mathbf{C}) \mathrm{y}=17.21(6.479)+1.758(0.495) \mathrm{x}, r^{2}=0.195$. Dotted line represents mean of final trunk diameter across treatments.

calipers than those planted $1.3 \mathrm{~cm}$ deep, whereas height was greater for trees planted $1.3 \mathrm{~cm}$ deep compared with planting at 6.4 , $8.9,11.4$, and $19.0 \mathrm{~cm}$ deep (Gilman and Harchick, 2008). Thus, like in our study, they found that deeper planting benefited diameter growth; however, in contrast to our study, they found that height growth was reduced by deeper planting. Gilman and Harchick (2008) also found that root damage increased when trees were planted very deep $(19 \mathrm{~cm}$ from the substrate surface), something that we did not observe in our study, although we did not plant the original root collar deeper than $10 \mathrm{~cm}$ in our study. The substrate used for Gilman and Harchick's (2008) study con- tained 60 pine bark:40 peat:10 sand (v:v:v) substrate, which is finer and results in peat filling pore spaces in between bark particles, which may increase water-holding capacity and reduce aeration compared with a coarser mix.

Deep planting in the field reduced the final tree height by $10 \mathrm{~cm}$ compared with trees planted above or at grade, but planting depth did not affect final trunk diameter or relative growth rates. There were few clear patterns in regard to final relation of root collar to soil line. At the end of the field experiment, nearly all of the treatment combinations with the tallest heights and/or greatest trunk diameters had the original root collars within the range of $5 \mathrm{~cm}$ above grade to $5 \mathrm{~cm}$ below grade, whereas nearly all of the treatment combinations with the shortest heights and smallest trunk diameters had their original root collars planted greater than $5 \mathrm{~cm}$ above grade or $5 \mathrm{~cm}$ below grade. This suggests that even with a species that is relatively tolerant to belowgrade planting, it will likely perform better in the landscape if it is planted with the original root collar near soil grade, whereas if the root collar is excessively above or below grade, growth is reduced. There are contrasting results reported in the literature indicating that results may be dependent on species, environmental conditions, and/or cultural practices. For example, Day and Harris (2008) reported that growth and establishment of Corylus colurna L. (Turkish hazel) trees was not impaired after nearly 8 years by planting root collars $15 \mathrm{~cm}$ or $30 \mathrm{~cm}$ below grade compared with at grade in a well-drained Groseclose silt loam field soil. In contrast, Wells et al. (2006) reported that when balledand-burlapped Yoshino cherry (Prunus xyedoensis Matsum.) trees were planted in an eroded Cecil sandy loam with root flares at $15 \mathrm{~cm}$ or $31 \mathrm{~cm}$ below grade, $50 \%$ of the trees died within 2 years of transplanting, whereas all trees planted with root flares at grade survived. This was attributed to reduced water infiltration to the root ball and insufficient access to shallow mineral nutrient pools (Wells et al., 2006). Arnold et al. (2007) reported that the growth of crapemyrtle (Lagerstroemia indica L. $\times$ Lagerstroemia fauriei Koehne. 'Basham's Party Pink'), green ash ( $F$. pennsylvanica), oleander (Nerium oleander L. 'Cranberry Cooler'), sycamore (Platanus occidentalis L.), and vitex (Vitex agnus-castus L. 'LeCompte') was adversely affected by planting the root collar $7.6 \mathrm{~cm}$ below grade in a fine sandy loam underlain at a depth of 15 to $30 \mathrm{~cm}$ by hard clay pan. Planting above grade was beneficial for sycamore when compared with planting at or below soil surface grade (Arnold et al., 2007). Arnold et al. (2005) suggested that in denser soil, planting the root collar deep may result in poor growth, possibly as a result of decreased soil moisture and/or oxygen content. The soil in the Arnold et al. (2007) and Wells et al. (2006) studies had higher clay contents than that in the Day and Harris (2008) study and our current study. Clay soils tend to have poor water movement, 
reduced oxygen content, and/or mechanical impedance of roots (Miller and Gardiner, 1998), and thus deep planting is more likely to be detrimental in clay soils than in the well-drained soils used in the Day and Harris (2008) study and our current study (77\% sand).

Growth of the lacebark elm used in this study was initially reduced by deep planting in container production when the containers were small $(10.8 \mathrm{~L})$. This may not be surprising for height as a result of the nature of the study (planting depth) because the height measurement was measured from the substrate surface. Thus, our height results need to be interpreted with caution; however, both diameter growth and total mass were also significantly reduced by deep planting, thus indicating the detrimental effect of deep planting lacebark elm trees into 10.8 -L containers.

Growth (as defined by mass or diameter) was not strongly affected and sometimes even enhanced by deep planting once the trees were transplanted into larger containers $(36.6 \mathrm{~L})$ and later established in field conditions. Potentially, lacebark elm was performing well in response to deep planting as a result of its tolerance or ability to avoid injury as a result of low soil oxygen (Armstrong and Drew, 2002); however, it is more likely that the sandy loam soil at our site allowed for good soil aeration. Results might have been different if the trees were transplanted into a more clay-based soil. The correlation between initial height and final height in the field was unaffected by container transplanting (upcanning) practices in this study; thus, the effect of planting depth during container production was less important in the subsequent landscape establishment of lacebark elm than the final deviation of the original root collar from the soil line when transplanted to the field, which may not be the same for all species. Effect of production method on landscape establishment is variable and may be short-lived, i.e., once in the field, trees seem to adapt regardless of production method. Harris and Gilman (1993) reported that with proper irrigation, production method (plastic container, fabric container, or field-grown) had no significant effect on trunk diameter increase after $\approx 1$ year. Davies and Albrigo (1994) suggested that transplanted large citrus (Citrus L.) trees tended to grow faster than small citrus trees initially but that this difference disappeared after 5 years in the field.

\section{Conclusion}

During initial container production (10.8 L), deep planting reduced tree growth compared with planting at grade. After transplanting into larger $(36.6 \mathrm{~L})$ containers, tree growth was variable across planting depths. Trees planted above grade in sequential upcannings had reduced growth when compared with trees planted initially (10.8-L container) above substrate grade and then subsequently (36.6-L container) planted below substrate surface grade. The reduced growth in container production could affect sale and marketability of trees from nurseries and thus planting depth is an important factor during potting up.

Once transplanted to the field, planting the original root collar more than $5 \mathrm{~cm}$ above or below grade generally resulted in reduced tree size, although the effects were small. Relative growth rates, which are unbiased with regard to starting tree size, were unaffected by field planting depth, indicating that lacebark elm is very tolerant to a range of planting depths. This tolerance could be species-specific or the result of the welldrained soil at the field site and/or possibly the result of the formation of mycorrhizal associations that may help overcome environmental stresses.

\section{Literature Cited}

Armstrong, W. and M.C. Drew. 2002. Root growth and metabolism under oxygen deficiency, $\mathrm{p}$. 729-762. In: Waisel, Y., A. Eshel, and U. Kafkafi (eds.). Plant roots: The hidden half. Marcel Dekker, Inc., New York, NY.

Arnold, M.A., G.V. McDonald, and D.L. Bryan. 2005. Planting depth and mulch thickness affect establishment of green ash (Fraxinus pennsylvanica) and bougainvillea goldentree (Koelreuteria bipinnata). J. Arbor. 31:163170.

Arnold, M.A., G.V. McDonald, D.L. Bryan, G.C Denny, W. Todd Watson, and L. Lombardini. 2007. Below-grade planting adversely affects survival and growth of tree species from five different families. Arboriculture and Urban Forestry 33:64-69.

Ball, J. 1999. Plant health care CEU series part VI: Tree planting: The foundation of PHC. Arborist News 8:53-58.

Browne, C. and K. Tilt. 1992. Effects of planting depth on three ornamental trees. Southern Nursery Assn. Res. Conf. 37:123-125.

Bunt, A.C. 1988. Media and mixes for containergrown plants: A manual on the preparation and use of growing media for pot plants. 2nd Ed. Unwin Hyman Ltd., London, UK.

Davies, F.S. and L.G. Albrigo. 1994. Citrus. CAB International, Wallingford, UK.

Day, S.D. and J.R. Harris. 2008. Growth, survival, and root system morphology of deeply planted Corylus colurna 7 years after transplanting and the effects of root collar excavation. Urb. For. \& Urb. Greening 7:119-128.

Day, S.D., G. Watson, P.E. Wiseman, and J.R. Harris. 2009. Causes and consequences of deep structural roots in urban trees: From nursery production to landscape establishment. Arbor. \& Urb. For. 35:182-191.

Drilias, M.J., J.E. Kuntz, and G.I. Worf. 1982. Collar rot and basal canker of sugar maple. J. Arbor. 8:29-33.

Fare, D.C. 2005. Should potting depth be a concern for container trees? p. 25-28. In: Watson, G. and A. Hewitt (eds.). Trees and planting: Getting the roots right conference proceedings. Morton Arboretum, Lisle, IL.

Giblin, C., J. Gillman, D. Hanson, G.R. Johnson, and P. Weicherding. 2005. The effects of soil depth on the long-term health and frequency of storm damage to trees in the upper Midwest, $p$. 33-39. In: Watson, G. and A. Hewitt (eds.). Trees and planting: Getting the roots right conference proceedings. Morton Arboretum, Lisle, IL.

Gilman, E.F. and J. Grabosky. 2004. Mulch and planting depth affect live oak (Quercus virginiana Mill.) establishment. J. Arbor. 30:311317.

Gilman, E.F. and C. Harchick. 2008. Planting depth in containers affects root form and tree quality. J. Environ. Hort. 26:129-134.

Harris, J.R. and E.F. Gilman. 1993. Production method affects growth and post-transplant establishment of 'East Palatka' holly. J. Amer. Soc. Hort. Sci. 118:194-200.

Hoffman, W.A. and H. Poorter. 2002. Avoiding bias in calculations of relative growth rate. Ann. Bot. (Lond.) 80:37-42.

Miller, R.W. and D.T. Gardiner. 1998. Soils in our environment. 8th Ed. Prentice-Hall, Inc., Upper Saddle River, NJ.

U.S. Department of Agriculture. 2007. Nursery crops, 2006 summary. Agricultural Statistics Board, NASS, USDA. 21 May 2009. <http:// usda.mannlib.cornell.edu/usda/current/NursProd/ NursProd-09-26-2007.pdf>.

U.S. Department of Agriculture, Natural Resources Conservation Service, Texas Agricultural Experiment Station, Texas State Soil and Water Conservation Board. 1991. General Soil Map: Brazos County, TX. Washington, DC.

Wells, C., K. Townsend, J. Caldwell, D. Ham, E.T. Smiley, and M. Sherwood. 2006. Effects of planting depth on landscape tree survival and girdling root formation. Arbor. Urban For. 32:305-311. 